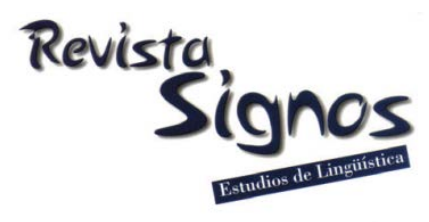

\title{
Textual genres and writing difficulties in specialized domains*
}

\section{Géneros textuales y dificultades de redacción en ámbitos especializados}

\section{Iria da Cunha}

UNIVERSIDAD NACIONAL DE EDUCACIÓN A DisTANCIA (UNED)

SPAIN

iriad@flog.uned.es

\author{
M. Amor Montané \\ UNIVERSITAT POMPEU FABRA \\ SPAIN \\ amor.montane@upf.edu
}

Recibido: 01-III-2017 / Aceptado: 29-VI-2018

DOI: $10.4067 /$ S0718-09342019000100004

\begin{abstract}
Writing is widely believed to be more difficult than reading comprehension. This difficulty is even greater for specialized texts; as a type of specialized communication, they must obey concrete norms, which can vary based on domain or textual genre. This article aims to identify the most frequently written genres and greatest writing challenges among different groups (specialists, students, and laypersons) in the specialized domains of medicine, tourism and the public administration and to identify the major writing difficulties they pose. A series of in-person interviews and online surveys were conducted. Quantitative and qualitative analysis shed light on the textual genres posing the greatest writing difficulties for the target groups and the causes thereof.
\end{abstract}

Key Words: Textual genre, specialized writing, medicine, tourism, public administration. 


\section{Resumen}

Es sabido que, por lo general, es más difícil la producción escrita que la compresión lectora. Con respecto a la escritura de textos especializados, la dificultad es aún mayor, ya que son fruto de la comunicación especializada y han de tener unas características concretas que además pueden variar en función del ámbito en el que se produzcan o de su género textual. El objetivo de este trabajo es detectar los géneros más frecuentes y más difíciles de escribir por parte de varios colectivos (especialistas, estudiantes y legos) en diferentes ámbitos especializados, junto con las principales dificultades de redacción. Concretamente, los ámbitos estudiados son la medicina, el turismo y la administración pública. Empleamos una metodología basada en entrevistas presenciales y encuestas en línea. Una vez realizadas, se obtienen, por un lado, resultados cuantitativos que permiten detectar los géneros textuales que presentan mayores dificultades de redacción a los colectivos estudiados y, por otro, resultados cualitativos sobre las causas que las provocan.

Palabras Clave: Género textual, redacción especializada, medicina, turismo, administración pública.

\section{INTRODUCTION}

Reading and writing are two fundamental skills that are part of our daily lives. Though people struggle with the reading-related processes, they are bound to face even greater difficulties with writing-related processes, since writing is more difficult than reading comprehension (Parodi, 2001; Cassany, 2009). This difficulty increases for specialized texts. Indeed, as a type of specialized communication, specialized texts must obey concrete norms, which can vary depending on the domain in which they are produced (Cabré, 1999). These domains include, inter alia, medicine, economics, law, tourism, environmental issues, and politics. Many students who graduate from university struggle to write texts such as scientific articles or abstracts. However, they will later need to be able to produce such texts during their professional careers. The same is the case with professionals -including doctors, lawyers, and economists- who occasionally face similar struggles, even though these texts are part of their everyday professional lives. Finally, from time to time, ordinary citizens must also write texts with which they are not familiar, including legal or administrative documents including statements and complaints.

Against this backdrop, this article aims to determine the most frequent textual genres and greatest writing challenges for three different groups (professionals, students, and laypersons) in several specialized domains and to identify the major writing difficulties they pose. This article examines three major fields: healthcare and science (concretely, family medicine), legal and economic affairs (concretely, public administration), and services (concretely, tourism). These fields and domains were selected because they have a major impact on the Spanish society, as the Plan for the Advancement of Language Technology (SESIAD, Spanish State Secretariat for Information Society and Digital Agenda, 2015) indicates. The general objective of this 
plan is to encourage the development of natural language processing and automatic translation in Spanish and co-official languages. The main domains of this plan are first health, tourism and education, and, second, justice, attention to the citizen and surveillance. From these six domains, we have selected three of them for our research: healthcare is crucial for the lives of all citizens; legal and economic affairs are of great importance in light of the current financial crisis and the frequent interactions between citizens and the public administration, so the attention to the citizen is a priority; and the services industry (especially tourism) is a key economic pillar upon which the Spanish economy is based.

As mentioned above, this study considers three different target populations. In the fields of family medicine and tourism, the article focuses on healthcare professionals (specially doctors) and tourism professionals (such as consultants of tourist companies, travel agents, tour guides or people who manage tourist applications or platforms) and university students pursuing studies in these fields. In the case of the public administration, this study simply focuses on average citizens.

In summary, the three domains are very different, because they have different purposes and profile users. However, we want to emphasize that the analysis we propose does not intend to make a comparison between the genres of each specialized domain, but only between the writing difficulties that these genres can suppose for their users. We consider that comparing them is interesting in order to see the similarities in such different specialized fields.

Section 1 presents a brief reflection on textual genres and specialized domains, focusing on the domains selected. Section 2 discusses methodology, while Section 3 presents results. Finally, the article ends by laying out conclusions and possibilities for future research.

\section{Textual genres and specialized domains}

The concept of textual genre has been defined in a variety of ways. For example, Swales (1990: 58) states that, "In addition to purpose, exemplars of a genre exhibit various patterns of similarity in terms of structure, style, content and intended audience". However, scholars have tended not to coalesce around a single definition of textual genres. As Parodi (2008) notes, it would be inappropriate to limit a definition to a single perspective, since "contextual, social and cognitive limitations and parameters" must be considered (Parodi, 2008: 26).

Textual genres are a key component of specialized discourse, and are related to the communicative context of a given discourse community (Gotti, 2008). By becoming familiarized with the various textual genres utilized in a given professional context and the specific characteristics thereof- professionals and specialists working in this domain will be able to produce these textual genres as part of their daily work. 
Students pursuing studies in a given field should also be familiar with the textual genres that are frequently utilized in their field. To this end, Cabré (2005, online; our translation) argues that:

"In every professional domain, documents corresponding to textual genres are used. Students should be knowledgeable about the characteristics of each genre so as to be able to generate texts that respect the social conventions of that genre, regardless of the topic at hand or the degree of abstraction."

As several scholars, including Bhatia (1993) and Parodi (2008), have noted, certain textual genres can be viewed as pertaining to a specific domain: for example, recipes are part of the culinary domain, and laws pertain to the legal domain. However, other genres - including, inter alia, research articles, reports, formal letters, and theses- are crosscutting, extending beyond specialized domains and remaining largely unchanged in different disciplines. In this sense, according to Parodi (2010), a distinction can also be made between professional genres (such as business plan and patient record) and academic genres (such as $\mathrm{PhD}$ thesis and master's thesis). The former are mostly written by professionals and the latter are mostly written by students.

Many studies have analyzed the textual genres that are generated in specific specialized domains. The scientific field, and specially the medical domain, is one of the most formalized and studied specialized fields internationally. Related to the medical domain, Piqué-Angordans and Posteguillo (2006: 651) argue that:

"Most of these genres are found in many other academic disciplines; however, each of them develops a set of peculiarities characteristic of the medical profession alone".

In this same domain, Gotti and Salager-Meyer (2006) highlight various studies discussing specific textual genres including, inter alia, abstracts (Salager-Meyer, 1990; Ciapuscio, 1998; da Cunha, 2008), research articles (Swales, 1990; Skelton, 1994; Nwogu, 1997; Marco, 2000; Li \& Ge, 2009), letters to the editor (Magnet \& Carnet, 2006), medical histories (Poirier \& Brauner, 1990), and case reports (Helán, 2012). Recently, Faya (2016) proposes a textual typology for the medical domain.

Tourism is an emerging domain and is linked with the economic activity. Reference works such as Calvi (2006, 2010) and Calvi and Mapelli (2011) present a detailed analysis of textual genres generated in this domain and suggest an approach for classifying them. Other works in this domain have examined specific textual genres such as travel guides (Mapelli, 2016), promotional texts (Rodríguez Abella, 2013), hotel websites (Cheng, 2016), travel blogs written by non-professionals (Goethals, 2013), descriptive guides (Mapelli, 2013) and touristic newsletters (Rodríguez Abella, 2014). Some other works compare different textual genres, such as blogs and internet newsgroups (Mapelli \& Piccioni, 2011), blogs and travel websites 
(Martínez Escalona, 2012), and hotel websites and research articles (Suau-Jiménez \& Piqué-Noguera, 2017). Likewise, textual genres of tourism are used in university didactic contexts (Escobar, 2011) and in works that focus on the writing of textual genres, such as the business plan (Barringer, 2014).

Finally, the administration domain has also studies and traditions, such as the plain language (which the Plain Language Action and Information Network ${ }^{1}$ started) and the training of public servants. However, it is a more local domain. In this work, we focus on citizens as producers of texts addressed to the administration. From this point of view, a number of works on legal and administrative texts have described and characterized the textual genres utilized in the Spanish public administration domain (e.g. Ayala, Domínguez, Martel, Montelongo, Morales, Socorro \& Suárez, 2000; Castellón, 2001; Sánchez Alonso, 2014). Moreover, the literature usually offers document templates (Ministerio de las Administraciones Públicas, 2003).

Texts corresponding to a given textual genre in a specialized domain are not easy to write. However, some authors (e.g. Cassany, 2007; Montolío, 2014) have penned style guides to help simplify this task for writers. Recent research has also considered approaches for teaching students to write for specific textual genres in the academic and professional domains; for example, abstracts (Parodi, Ibáñez \& Venegas, 2014) and bachelor's and master's theses (Meza, 2015; Venegas, Núñez, Zamora \& Santana, 2015; da Cunha, 2016). There are also several works that analyze the writing difficulties faced by professionals from different specialized fields: on the one hand, those that deal with the writing of academic texts or research articles in general. For example, Pano, Picón and Attorresi (2004) classify the writing difficulties into four categories: those related to motivation, those related to familiarity with the subject, contextual obstacles and linguistic competence. Fregoso (2008) detects six types of difficulties in writing: graphematic, verbal, lexical, syntactic, semantic and orthographic difficulties. Sabaj (2009) focuses on errors contained in participants' compositions: he found writing errors (orthography, punctuation and vocabulary) and genre-specific errors (formal aspects, hierarchy of information and structure). On the other hand, there are also works about writing difficulties in textual genres of specific specialized fields, such as Reimenerink (2003) and Moreno, Rodríguez, Vázquez, Ricardo and Rodríguez (2016) in medicine; Rodríguez de Benítez (2014) in tourism, and González Salgado (2009) in the judicial field. Some other works are especially focused on the study of language and genres of a specialized field, such as Calvi (2006) for the language of tourism.

To our knowledge, no studies have considered which textual genres pose the greatest writing difficulties for a given group (professionals, students, or the general public) in a specialized domain or researched the frequency with which these genres are produced in these domains. This paper uses empirical data to shed light on these two questions. 


\section{Methodology}

This study adopted a multi-stage methodology. First, the literature on textual genres in Spanish in the domains of medicine, tourism and the public administration was examined. Based on this literature review, a preliminary list of textual genres was derived for each domain. Specifically, for medicine, the genres indicated by Gutiérrez (1998) and Faya (2016) were included; for tourism, the genres included in Calvi (2006, 2010) and Calvi and Mapelli (2011) were selected, and, for public administration, the genres mentioned in Ayala et al. (2000), Castellón (2001) and Sánchez Alonso (2014) were chosen.

Second, five qualified specialists (including instructors and professionals) in these three domains ${ }^{2}$ were interviewed. The same interview was carried out for each domain. These interviews served a threefold purpose: to fine-tune the list of genres derived from the literature review, to identify writing difficulties, and to gather information on university-level writing classes. Although the questions were slightly adapted for each domain, the same general types of questions were included in each interview. ${ }^{3}$ By way of example, Table 1 reproduces the questions the medical school faculty member was asked to answer.

Table 1. Interview questions: Medical school faculty member.

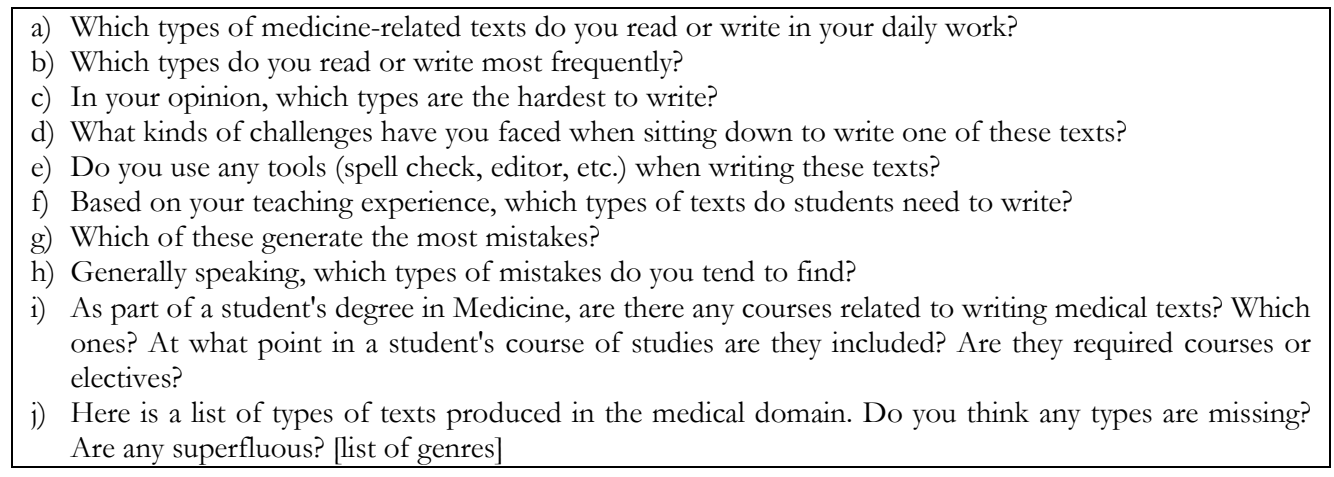

Based on feedback provided by these interviews, especially by the answer to question (j), the lists of textual genres utilized in this study were finalized; these are presented in Table 2 Table below. In the medical domain, textual genres included texts that doctors write on a regular basis in their professional lives, including medical histories, progress notes, case reports, etc. Based on the responses to interview questions, it became clear that medical professionals also frequently work as researchers. Consequently, the list of textual genres also included research-related terms such as research article, $\mathrm{PhD}$ thesis, review article, etc. As noted above, these crosscutting genres are used in a variety of specialized domains. However, in the domain of tourism, experts confirmed that professionals (including tour guides, consultants, travel agents, hotel managers, etc.) rarely double as researchers. For this 
study, research-related terms were therefore excluded from the list of textual genres in the field of tourism.

Table 2. List of textual genres utilized in this study.

\begin{tabular}{|c|c|c|}
\hline Medicine & $\begin{array}{l}\text { artículo de divulgación } \\
\text { artículo de investigación corto } \\
\text { artículo de investigación largo } \\
\text { artículo de revisión } \\
\text { carta al editor } \\
\text { carta de aceptación o rechazo de un } \\
\text { artículo de investigación } \\
\text { caso clínico } \\
\text { comunicación a congreso } \\
\text { editorial } \\
\text { folleto de salud } \\
\text { historia clínica } \\
\text { historial del paciente } \\
\text { informe técnico } \\
\text { libro } \\
\text { manual universitario } \\
\text { nota clínica } \\
\text { página web } \\
\text { programa de asignatura universitaria } \\
\text { programa de congreso o evento } \\
\text { académico } \\
\text { proyecto de tesis doctoral } \\
\text { reseña de libro } \\
\text { resumen de artículo de investigación } \\
\text { revisión por pares } \\
\text { tesis doctoral } \\
\text { TFG (trabajo final de grado) o tesis de } \\
\text { licenciatura o diplomatura } \\
\text { TFM (trabajo final de máster) o tesis } \\
\text { de final de máster o posgrado } \\
\end{array}$ & $\begin{array}{l}\text { popular science article } \\
\text { short research article } \\
\text { long research article } \\
\text { review article } \\
\text { letter to the editor } \\
\text { letter of acceptance/rejection of a paper } \\
\text { case report } \\
\text { conference paper } \\
\text { editorial } \\
\text { health fact sheet } \\
\text { medical history } \\
\text { patient record } \\
\text { technical report } \\
\text { book } \\
\text { textbook } \\
\text { progress note } \\
\text { webpage } \\
\text { syllabus } \\
\text { conference program } \\
\text { PhD proposal } \\
\text { book review } \\
\text { abstract } \\
\text { peer review } \\
\text { PhD thesis } \\
\text { bachelor's thesis } \\
\text { master's thesis }\end{array}$ \\
\hline Tourism & $\begin{array}{l}\text { artículo de divulgación } \\
\text { entrada de blog de viajero } \\
\text { catálogo de viaje } \\
\text { correo electrónico (en hoteles u otras } \\
\text { empresas propias del sector del } \\
\text { turismo) } \\
\text { guía de viaje } \\
\text { informe } \\
\text { itinerario de viaje } \\
\text { manual universitario } \\
\text { normativa } \\
\text { plan de negocios } \\
\text { plan de viaje } \\
\text { post en foro turístico }\end{array}$ & $\begin{array}{l}\text { informative article } \\
\text { travel blog post } \\
\text { travel brochure } \\
\text { email (e.g. emails written in hotels or other } \\
\text { enterprises in the tourism industry) } \\
\text { travel guide } \\
\text { report } \\
\text { travel itinerary } \\
\text { textbook } \\
\text { rules and regulations } \\
\text { business plan } \\
\text { travel plan } \\
\text { forum post }\end{array}$ \\
\hline $\begin{array}{l}\text { Public } \\
\text { administration }\end{array}$ & $\begin{array}{l}\text { Alegación } \\
\text { autorización } \\
\text { carta de presentación } \\
\text { carta formal } \\
\text { comunicación } \\
\text { currículum } \\
\text { declaración } \\
\text { declaración jurada }\end{array}$ & $\begin{array}{l}\text { allegation } \\
\text { authorization } \\
\text { cover letter } \\
\text { formal letter } \\
\text { notice } \\
\text { curriculum vitae } \\
\text { declaration } \\
\text { affidavit }\end{array}$ \\
\hline
\end{tabular}




\begin{tabular}{|l|l|l|}
\hline & declaración responsable & statement of responsibility \\
demanda & lawsuit \\
denuncia & accusation \\
instancia & formal request \\
justificación & statement of grounds \\
notificación & notification \\
oficio & official letter \\
petición & petition \\
queja & letter of complaint \\
querella & complaint \\
reclamación & claim \\
recurso contencioso-administrativo & administrative appeal \\
& recurso de revisión & appeal for revision \\
& recurso ordinario & ordinary appeal \\
& renuncia & letter of resignation \\
solicitud & application \\
sugerencia & suggestion \\
\hline
\end{tabular}

Furthermore, questions $(\mathrm{d})$ and $(\mathrm{h})$ provided information on difficulties that arise when writing specialized texts, revealing the challenges that specialists and students face when writing in these three domains. Based on this information and Cassany's (2007) and Montolío's (2014) professional and academic style guides, the authors drafted a list of potential difficulties that arise when writing specialized texts; this was included in the online surveys (see Table 3 Table 1 below).

Third, based on the literature review and interviews with specialists, the surveys were designed and created using the Google Forms online tool. Survey participants included: 4

- Family practitioners from the Spanish Society of Family and Community Medicine;

- $3^{\text {rd }}$, $5^{\text {th }}$, and $6^{\text {th }}$-year students pursuing a six-year undergraduate degree in medicine at the University of Barcelona (UB);

- Tourism experts who are members of the Spanish Confederation of Hotels and Tourist Accommodation (CEHAT) or the Hotel Technology Institute (ITH);

- 2nd-year students pursuing a four-year undergraduate degree in Tourism at the National Distance Education University (UNED); and

- Laypersons: Students enrolled in the UNED's Access Courses for those over 25.

The surveys had two goals: to identify (a) the most frequent, most challenging textual genres and (b) the most relevant difficulties in writing specialized texts in each domain. All surveys included three sections: 1) an introduction, which explained the purpose of the study; 2) basic information (age, gender, nationality, highest level of education attained, and where applicable, current year of studies); and 3) questions related to the frequency with which participants write a given text, degree of difficulty when writing a given text, and concrete difficulties encountered when writing texts in a given domain. As mentioned above, the surveys contained a closed list of textual 
genres, which varied for each domain, and a list of potential writing difficulties. This list was identical for all three domains because the final purpose is to compare the difficulties between domains, so the survey questions must be systematic. All surveys included an 'Other' category, where respondents could add additional genres or writing difficulties not included in the lists. Furthermore, students were also asked to answer a question about academic writing courses. By way of example, Table 3 includes the questions in section 3 of the survey distributed to tourism students.

Table 3. Questions from section 3 of the survey distributed to tourism students.

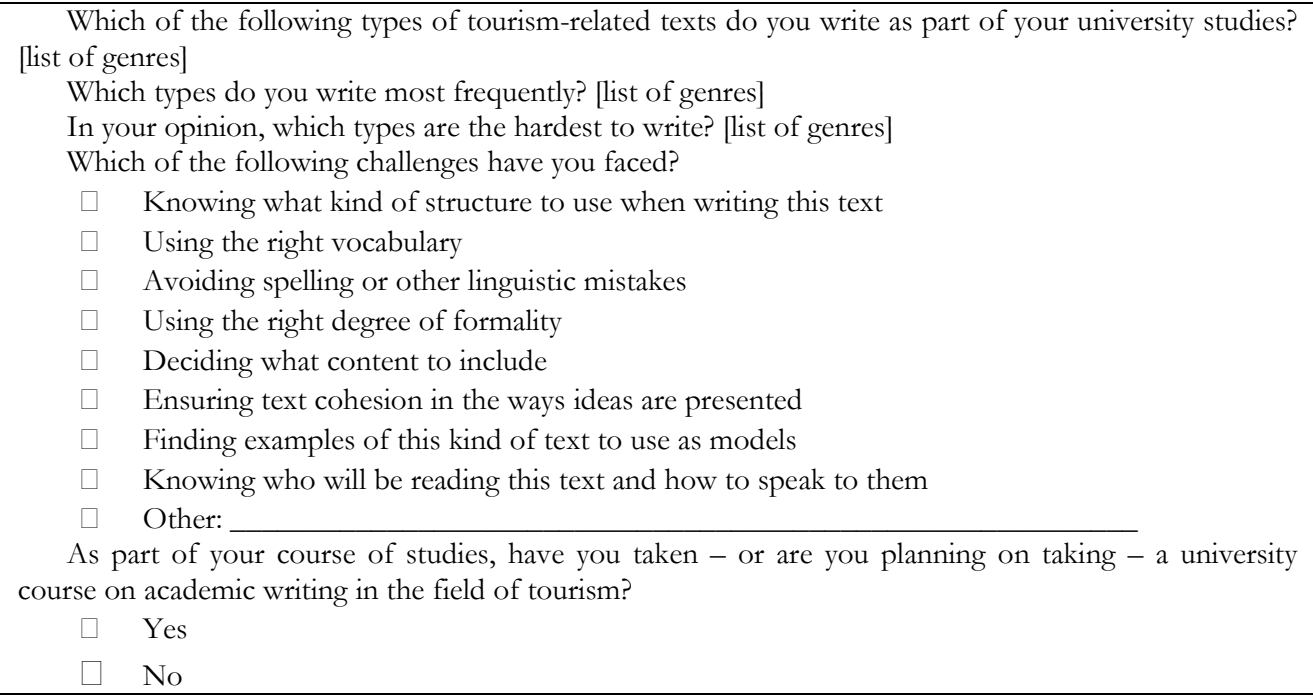

It is interesting to mention that all the recollected data (both from interviews and surveys) are obtained from the statements of the participants; therefore, they indicate what participants think about the textual genres of their corresponding domains.

Once all survey responses were collected, the results were analyzed quantitatively to study trends regarding: a) the frequency of writing and difficulty writing different textual genres in each domain and for each group; and b) the frequency of the different types of writing difficulties presented in Table 3. In the domains of family medicine and tourism, responses from students and professionals were first considered separately and then aggregated in order to identify general trends in each domain. As this study included only a single group of respondents (laypersons) for the public administration, results are not broken down in this fashion for this third domain.

\section{Results}

This section presents key findings of this study. Section 3.1 lays out the findings regarding frequency and difficulty of textual genres in each domain, while Section 3.2 
presents results related to difficulties when writing specialized texts in each of the domains considered.

All data presented in this section was collected using the online surveys. Four hundred twenty-one (421) survey responses were received:

- Family medicine: 146 responses: 57 from specialists and 89 from students;

- Tourism: 195 responses: 137 from specialists and 58 from students;

- Public administration: 80 responses from laypersons.

\subsection{Results: Frequency and difficulty of textual genres}

This section analyzes the survey responses for the three domains analyzed, discussing the frequency with which individuals write different textual genres and the degree of difficulty they face in doing so. Medicine and tourism data are broken down as subsets; first, the results for students and professionals are presented separately, and subsequently, overall results for the aggregated data set in this domain are discussed. For the third domain, public administration, results are based on the entire domainspecific data set as a whole.

\subsubsection{Textual genres in the medical domain}

Graph 1 presents responses from medical students and healthcare professionals about which textual genres they write most frequently in academic and professional contexts. The full set of quantitative data is available in Annex 1.

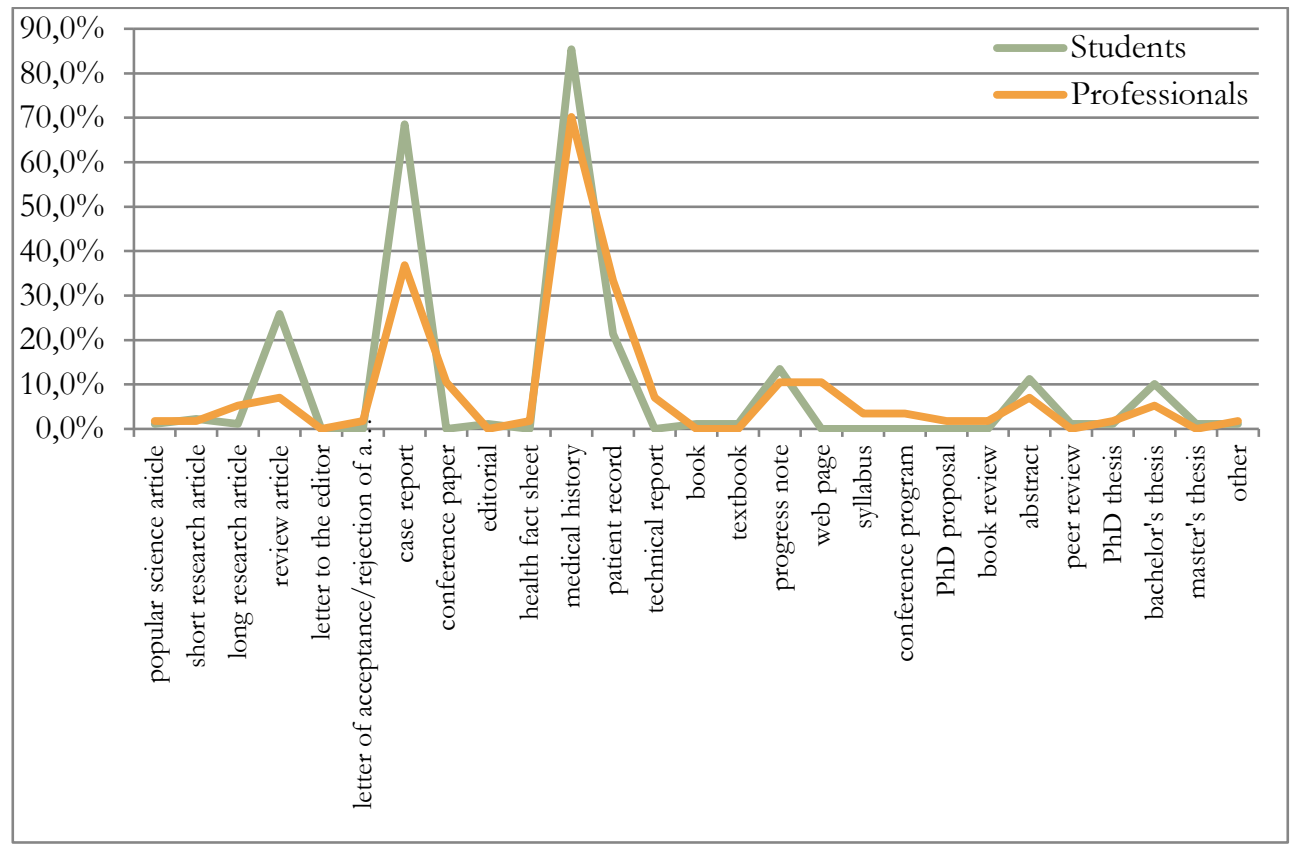

Graph 1. Results: Frequency of textual genres in the medical domain. 
As Graph 1 demonstrates, responses from students and professionals tended to overlap: both wrote 'medical histories' and 'case reports' most frequently. Percentages are similar for 'progress notes', 'abstracts', and 'bachelor's theses', although students claimed to write in these three textual genres more frequently than specialists. This comes as no surprise, since, for example, 'bachelor's theses' are only written by students enrolled in undergraduate programs. Students also wrote 'review articles' more frequently than professionals, whereas doctors wrote 'patient records', 'webpages' and 'conference papers' more frequently than students. All other textual genres were written only infrequently by both groups.

Graph 2 presents responses from medical students and healthcare professionals about which textual genres pose the greatest writing difficulties.

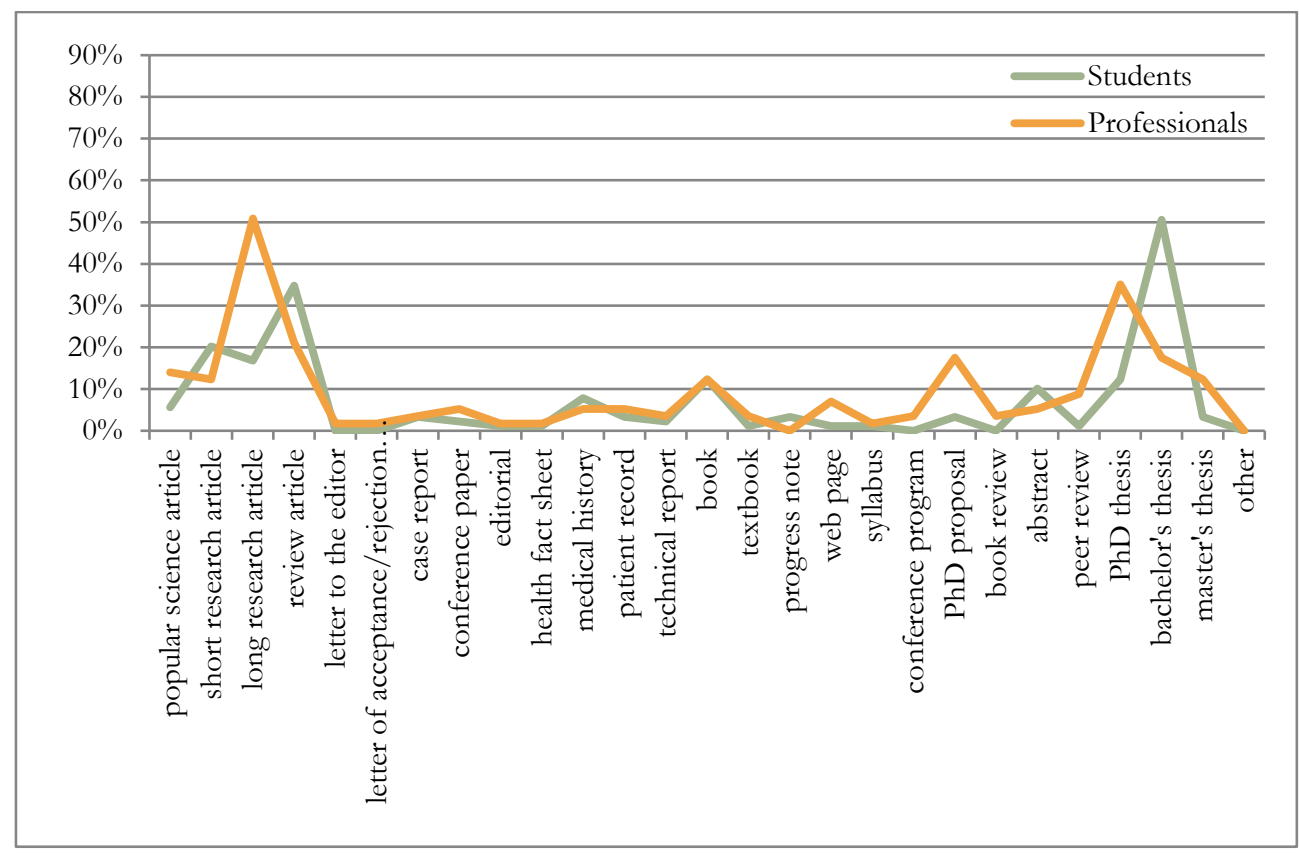

Graph 2. Results: Difficulty of textual genres in the medical domain.

In the medical domain, difficulties in writing different textual genres tended to vary between students and professionals (Graph 2 and Annex 1). While students found 'bachelor's theses' to be the most difficult to write, doctors argued that 'long research articles' were the most challenging textual genre. These genres do not tend to be written by both groups. Though a 'bachelor's thesis' is one of the most important texts students write during their undergraduate studies in Medicine, students tend not to have to write 'long research articles' while enrolled at the university; these are typically written by medical research scientists. Nevertheless, even though they are always produced in academic contexts, medical practitioners find that ' $\mathrm{PhD}$ theses', 'PhD proposals' and 'master's theses' tend to pose writing difficulties. In contrast, 
students believe that 'review articles' and 'short research articles' are difficult to write, even though they do not have to write them frequently during their studies.

Graph 3 presents overall results from both groups in the medical domain, and includes data on both frequency and difficulty of each of the genres analyzed in this domain.

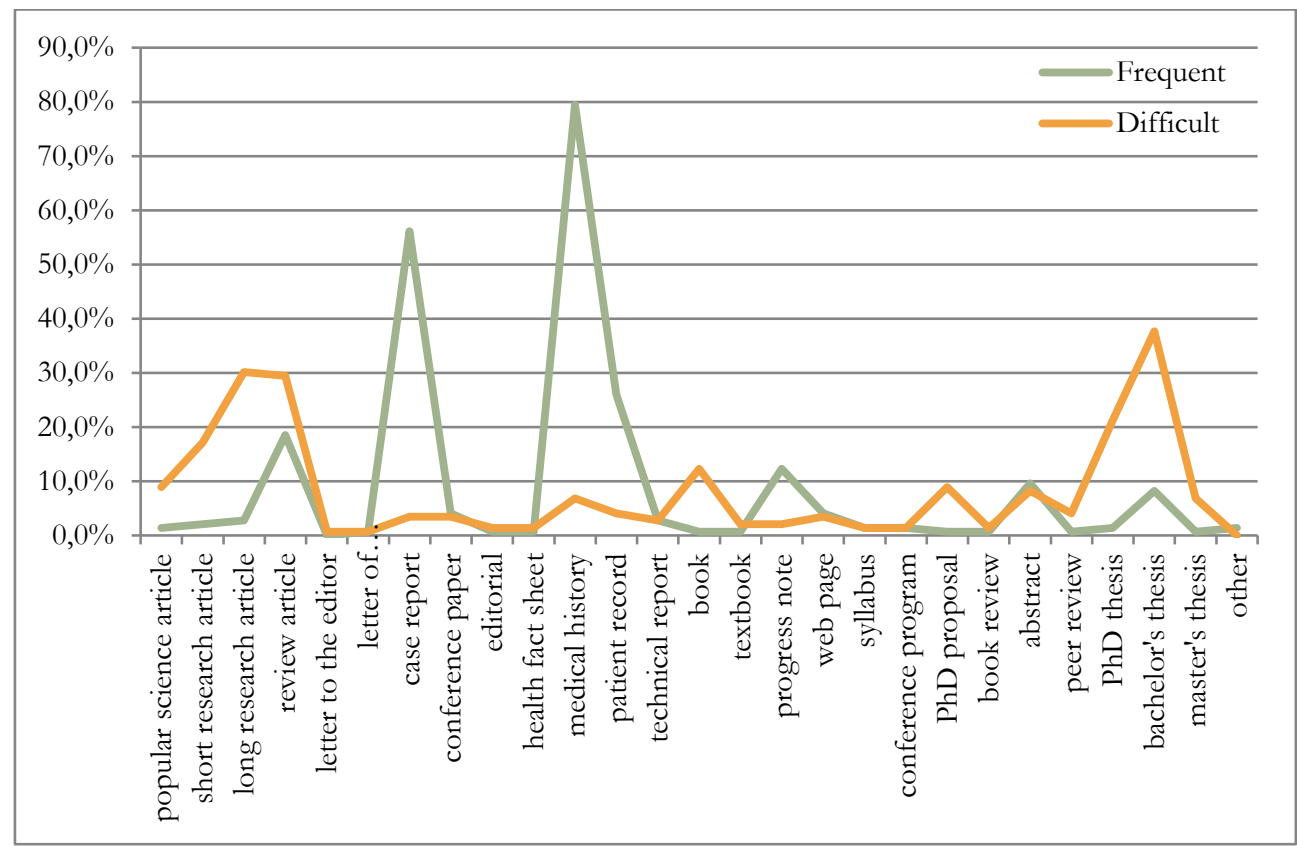

Graph 3. Results: Overall frequency and difficulty for textual genres in the medical domain.

As Graph 3 demonstrates, the most frequently written textual genres are the 'medical history', 'case report', 'review article', 'progress note', and 'abstract' (in descending order). (The exact percentages for each textual genre are presented in Annex 1.) Based on survey responses, the five most difficult textual genres to write are the 'bachelor's thesis', 'long research article', 'review article', 'short research article', and 'book' (in descending order). Consequently, according to respondents, the 'review article' is the only frequently written genre that is also difficult to write, as it appears among the top five responses in both categories. In two cases -the 'bachelor's thesis' and 'abstract'- respondents believed that relatively frequent genres (i.e. those picked by approximately $10 \%$ of participants) were difficult to write. Both 'long research articles' and 'short research articles' were written less frequently than other genres in the medical context (such as the 'medical history' and 'case report'). Nevertheless, almost twice as many respondents argued that a 'long research article' was difficult to write than those who claimed that a 'short research article' was difficult to write. In contrast, a 'medical history' was not seen as difficult to write, despite the fact that it is far and away the most frequent genre in the medical domain. 


\subsubsection{Textual genres in the tourism domain}

Graph 4 presents the textual genres that tourism students and professionals write most frequently in tourism-related contexts. Exact percentages are available in Annex 2.

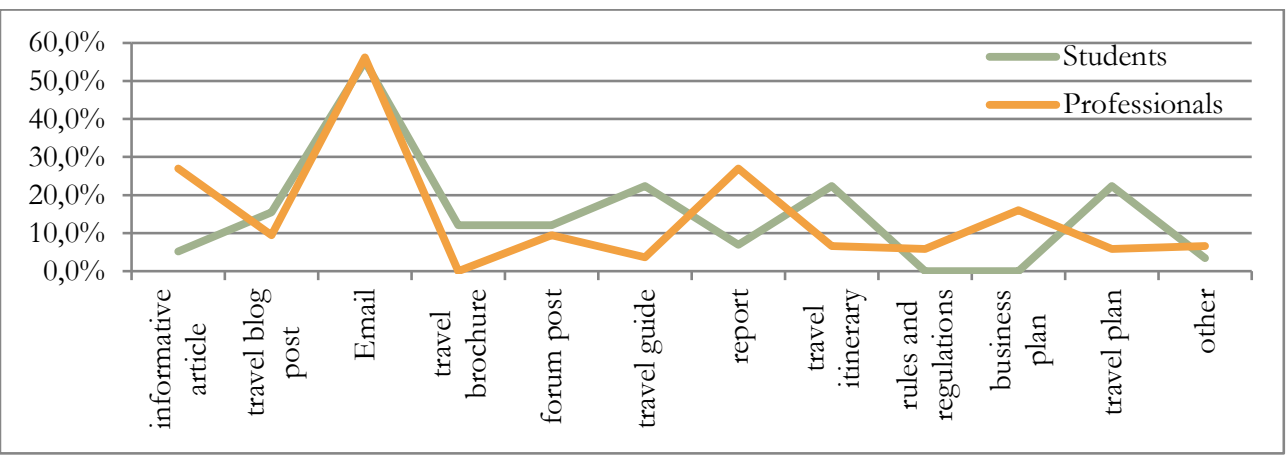

Graph 4. Results: Frequency of textual genres in the tourism domain.

Generally speaking, responses from tourism students and professionals tended to vary considerably (Graph 4 and Annex 2). The only similarities can be found in the case of the 'email', which both groups saw as very frequent, and the 'travel blog post' and 'forum post', which were much less frequent. As for differences, students regularly write 'travel plans', 'travel itineraries' and 'travel guides', while specialists do not. In fact, these genres are prototypical examples of classwork completed by students enrolled in the Bachelor's Degree in tourism, which explains why students write them so frequently. In contrast, tourism professionals claim to regularly write 'informative articles', 'reports' and 'business plans', which are a much more typical part of their work environment.

Graph 5 presents responses from tourism students and professionals about the difficulties they face when writing different textual genres in tourism-related contexts. 


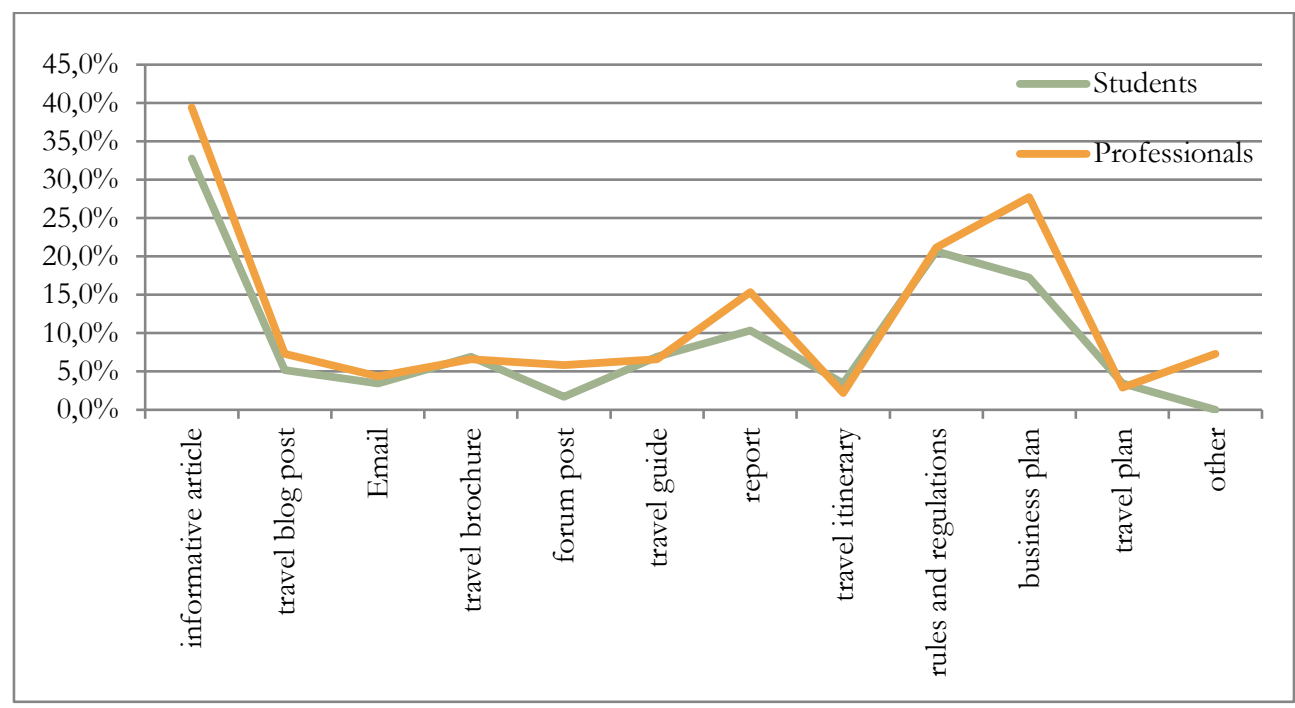

Graph 5. Results: Difficulty of textual genres in the tourism domain.

Unlike the results for frequencies presented above, students and professionals generally concur regarding the perceived difficulty of writing different textual genres in this field, as we can see from Graph 5 and Annex 2. The only genre where responses differed by more than $10 \%$ is the 'business plan', which professionals saw as more difficult to write. This is due to the fact that students have not yet learned how to write for this textual genre, as reflected by their responses in Graph 4. Consequently, unlike many tourism professionals, who write 'business plans' in their everyday professional lives, students may not be aware of the true difficulties that arise when writing this type of text. Graph 6 presents aggregated responses in the tourism domain.

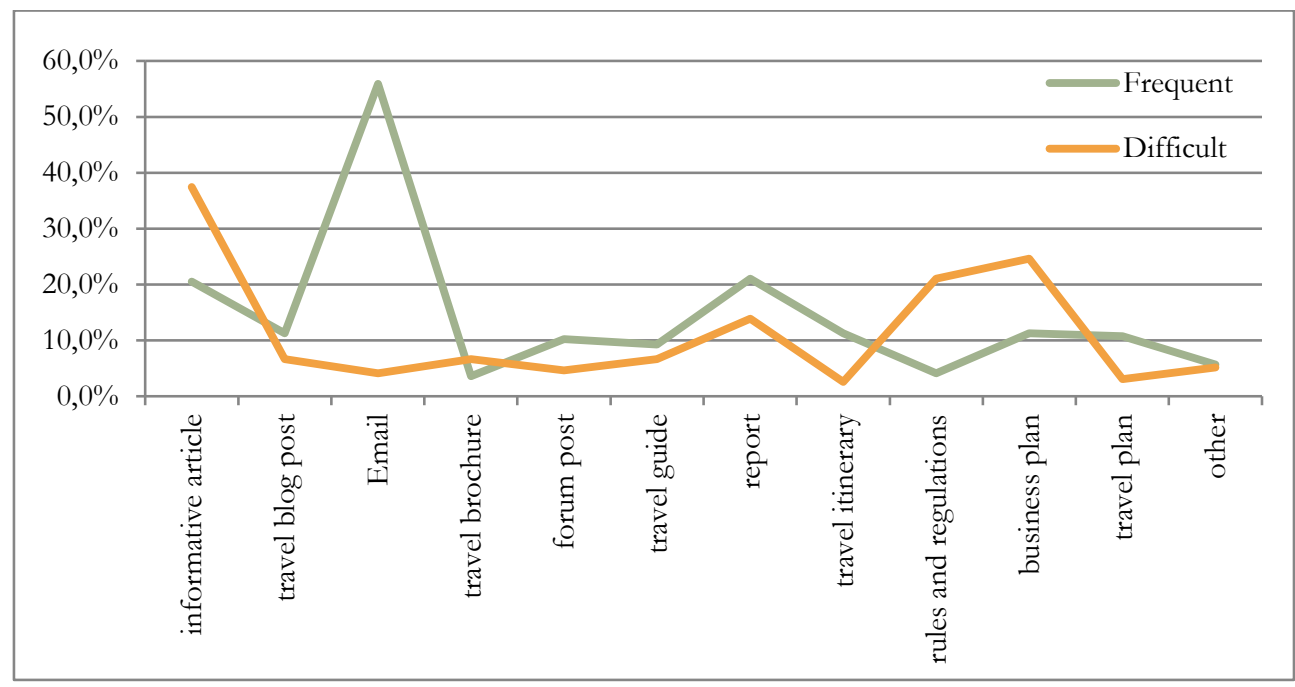

Graph 6. Results: Overall frequency and difficulty of textual genres in the tourism domain. 
As we can see, the five most frequent types of texts in this domain are 'emails', 'reports', 'informative articles', 'travel blog posts', and 'business plans' (in descending order). The four most difficult textual genres to write are 'informative articles', 'business plans', 'rules and regulations', and 'reports'; 'travel blog posts', 'travel guides' and 'travel brochures' tied for the fifth most difficult type of text to write. Four types of texts in the tourism domain -'informative articles', 'reports', 'business plans' and 'travel blog entries' -are all considered to be frequent and difficult to write. Though 'emails' were far and away the most frequent genre, they were not seen as difficult to write. In contrast, although 'rules and regulations' are written infrequently, they are viewed as one of the most difficult texts to write.

\subsubsection{Textual genres in the public administration}

Graph 7 presents results from laypersons regarding genres in the public administration. Comprehensive data are available in Annex 3.

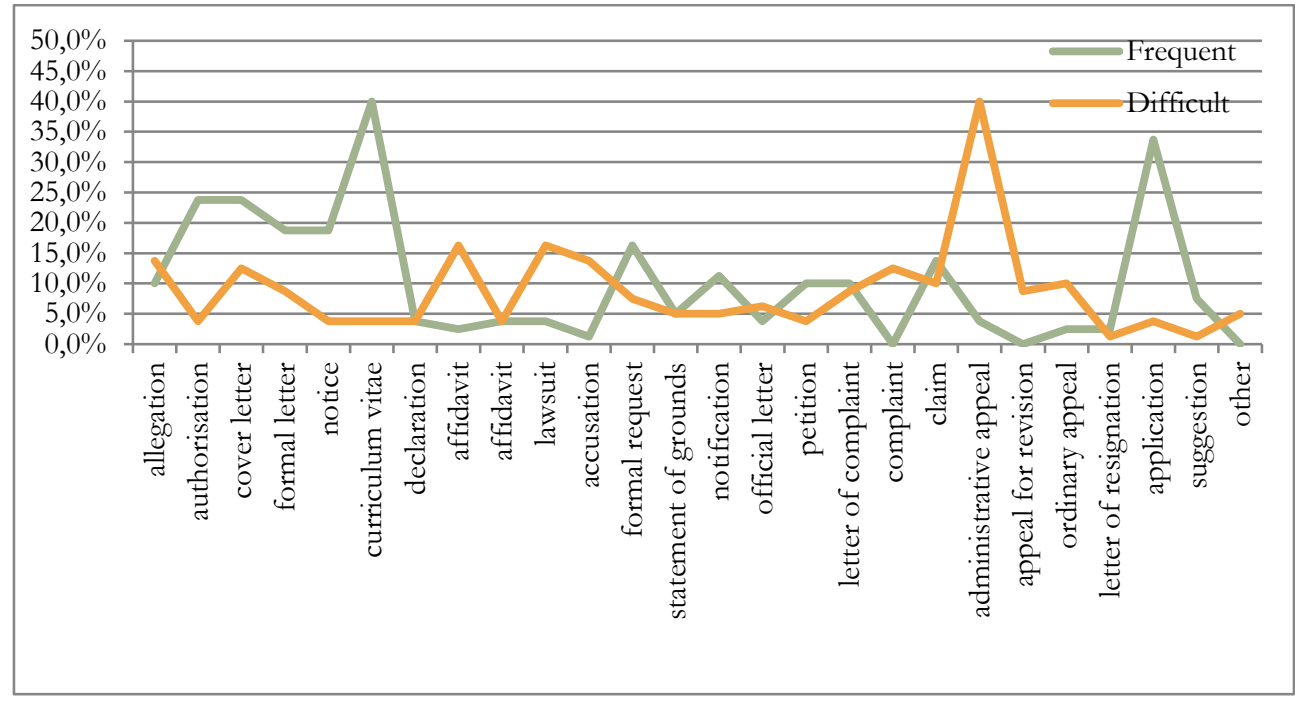

Graph 7. Results: Frequency and difficulty of textual genres in the public administration.

As the results presented in Graph 7 and Annex 3 demonstrate, laypersons claim that the four types of textual genres they have to write most frequently when corresponding with the public administration are 'curricula vitae', 'applications', 'authorizations' and 'cover letters'; 'formal letters' and 'notices' tied as the fifth most frequent textual genre in this domain. The five textual genres that laypersons found to be most difficult to write were 'administrative appeals', 'affidavits', 'lawsuits', 'allegations', and 'accusations' (in descending order). As we can see, the most frequently written and most difficult genres did not overlap. This is due to the fact that laypersons do not tend to write many of the textual genres included on the list over the course of their lifetimes, and therefore, tend to view genres that they have no experience with as the most difficult to write. 
The two most frequently written genres by a considerable margin are 'applications' and 'curricula vitae'. However, these are not seen as overly difficult to write. 'Cover letters' and 'authorizations' are also frequent, but the former is seen as more difficult to write than the latter, with a difference of nearly $10 \%$. When the two variables, frequency and difficulty, are cross-tabulated, the greatest overlaps are found in 'allegations' (which appear among the five most difficult types of genres to write), 'claims' and 'letters of complaints', since approximately $10 \%$ of laypersons selected them as both frequent and difficult genres.

\subsection{Results: Difficulties when writing specialized texts}

As indicated in Section 2, the surveys included a question that aimed to assess the difficulties respondents found when writing specialized texts in their domain (see Table 3). This section presents Graphs depicting the answers to this question, which are presented for each domain separately; differences between students and professional in the medicine and tourism domains are also noted. The full set of quantitative results is available in Annex 4. Graph 8 sets out the results from the medical domain.

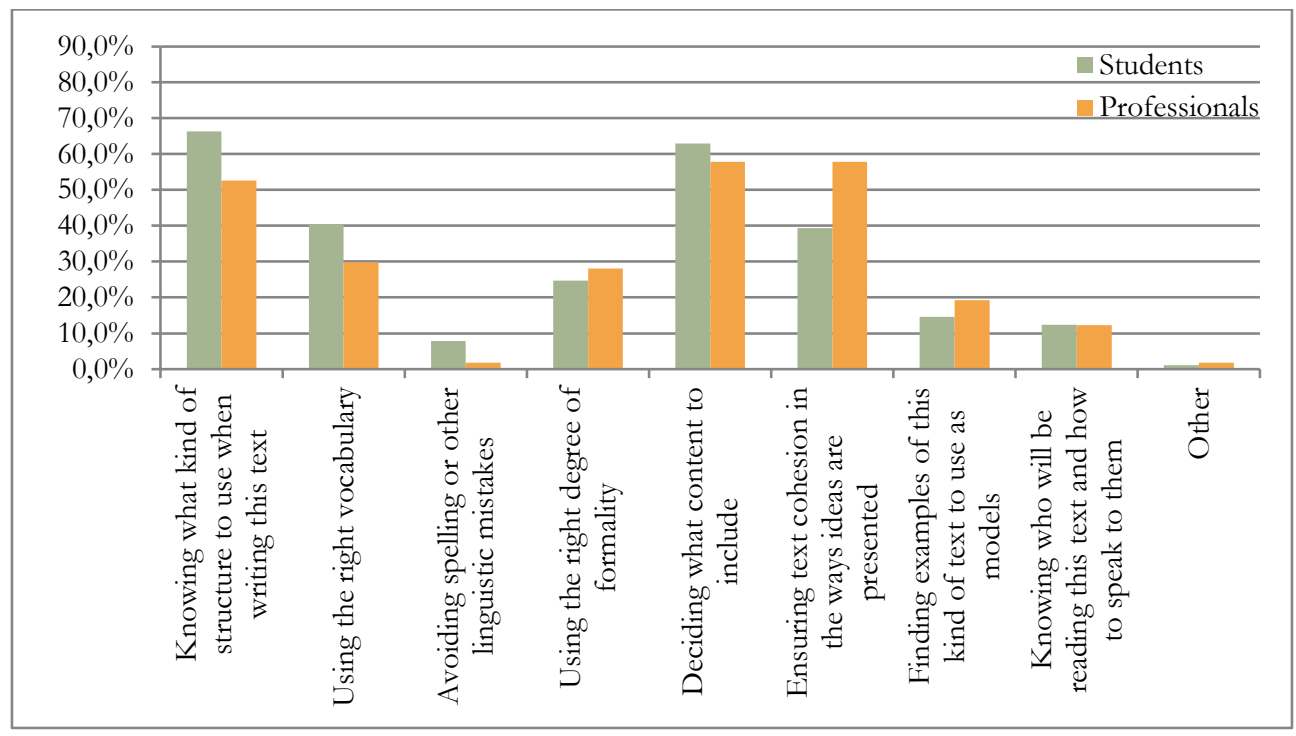

Graph 8. Writing difficulties in the medical domain.

For both groups, the most frequent difficulties were related to textual structure, selection of contents, and text cohesion. To a lesser extent, both groups also mentioned specialized vocabulary and the degree of formality. The most noteworthy differences between students and professionals were related to text structure (which was the most difficult issue for students) and text cohesion (the most frequent difficulty for specialists). Only two respondents checked the 'Other' box: one student mentioned difficulties in obtaining data on public health to use for writing texts, and 
one doctor indicated the challenge of ensuring that content and format went hand in hand, particularly for theses.

Graph 9 includes responses from the tourism domain.

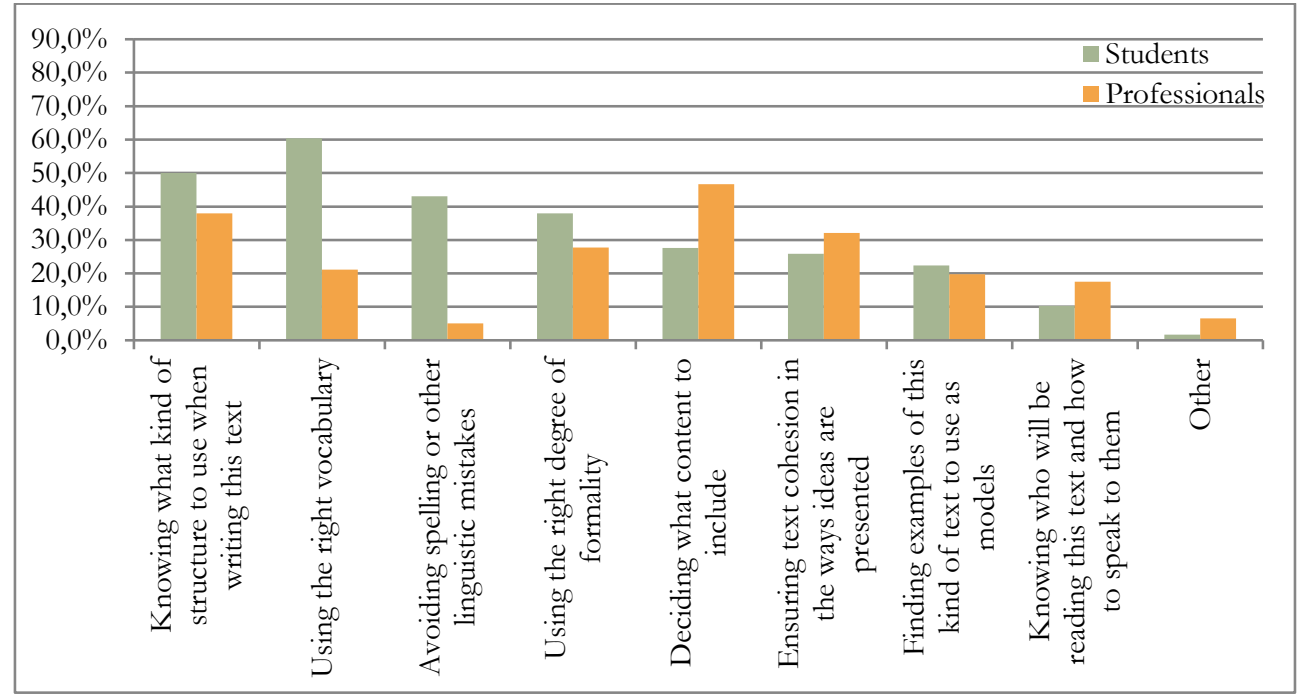

Graph 9. Writing difficulties in the tourism domain.

In this domain, results show greater differences between students and professionals. Students noted challenges related to vocabulary, spelling and other linguistic mistakes, whereas professionals struggled most with deciding which content to include in a given document. For both groups, writing difficulties included textual structure, text cohesion and the degree of formality. Moreover, in the 'Other' section, tourism professionals mentioned additional difficulties: ensuring that a text was appealing and useful for the tourism industry, summarizing a message to present a complicated concept simply, and presenting texts in an original way that would draw in the reader. No students ticked the 'Other' box.

Graph 10 presents the writing difficulties laypersons find in texts for the administration. 


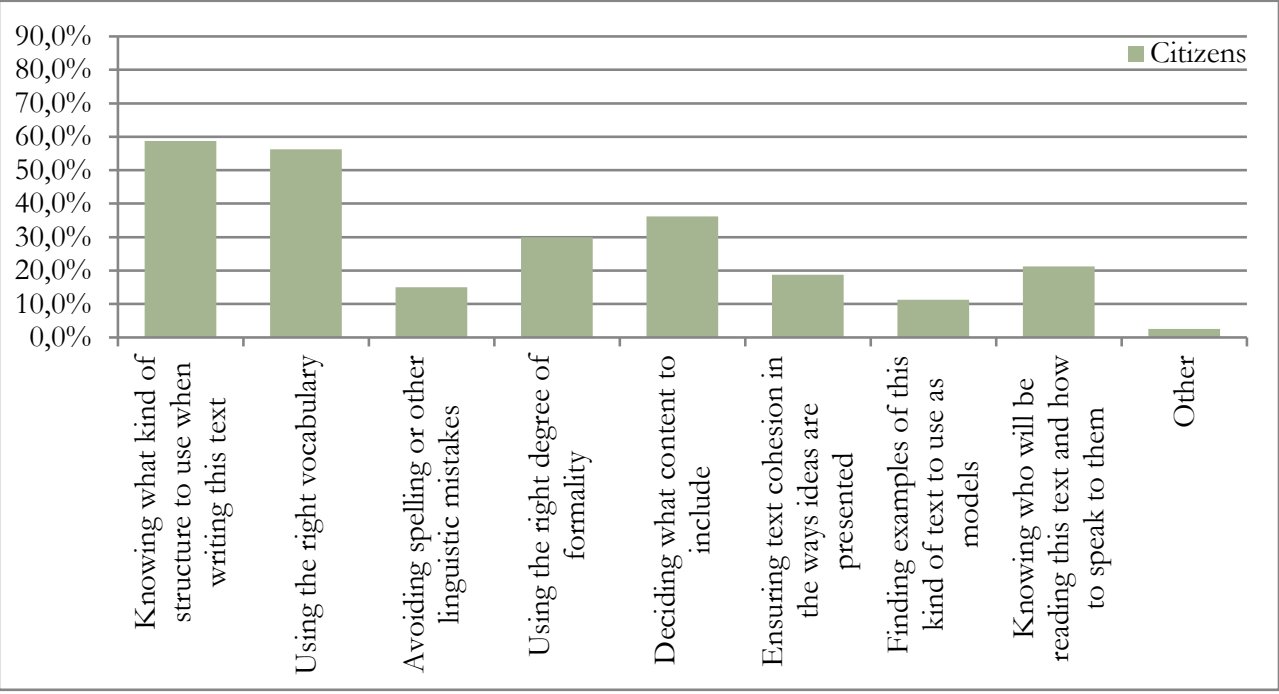

Graph 10. Writing difficulties in texts addressed to the public administration.

Laypersons struggled with two major challenges when writing texts addressed to administration: structuring the text and utilizing appropriate vocabulary for this communicative setting. Other difficulties appeared frequently: determining content and using an appropriate degree of formality. No respondents ticked the 'Other' box.

Finally, Graph 11 presents overall results for writing difficulties, broken down by specialized domain. (More comprehensive data and percentages are available in Annex 4).

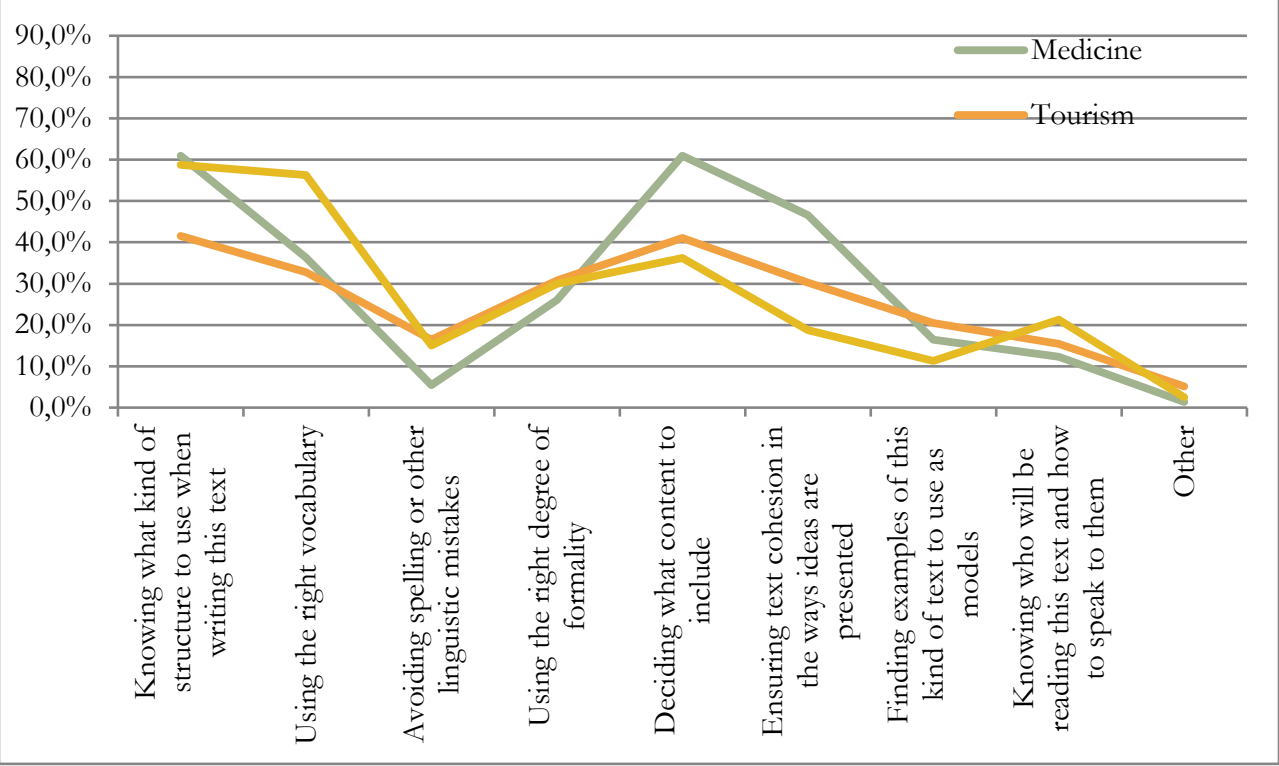

Graph 11. Overall results: Writing difficulties in the three domains studied. 
For all three domains, the most frequent difficulties were related to textual structure, content, and using appropriate vocabulary for the communicative setting, which are already mentioned in previous literature about writing difficulties (for example, Sabaj, 2009). The degree of formality and text cohesion were also mentioned frequently. In contrast, spelling and other linguistic mistakes, finding models to serve as examples and adapting the text to the addressee were aspects of academic writing that did not seem to prove particularly problematic for any of the surveyed groups. These results contrast with what the literature states, especially concerning spelling mistakes (Fregoso, 2008; Sabaj, 2009), although it is important to highlight that previous research focus only in students' texts. Difficulties that obtained a low frequency in our study might be related to the existence of spellcheckers and the availability of models on the internet.

\section{CONCLUSIONS AND FUTURE WORK}

This article has achieved its two primary objectives: to identify the most frequent textual genres and determine which genres pose the greatest writing difficulties in each of the specialized domains considered (family medicine, tourism, and the public administration) for different groups (professionals, students, and average citizens); and to identify the greatest difficulties in writing specialized texts in each of these domains. Since no prior research has examined the different groups involved in each specialized domain, this study can be considered to be original.

Furthermore, this research has clear repercussions for society as a whole and, more concretely, for the groups analyzed herein. It could contribute to general well being, helping laypersons to communicate better with the public administration. It could promote productivity among specialists, since identify writing difficulties and needs may help in drafting specialized texts. Finally, it could help students to improve their academic writing; indeed, this type of study may help universities to fine tune their courses in order to offer subjects that are better tailored to students' writing needs in these specialized domains.

The results for each of the textual genres in each domain are also noteworthy. By cross-tabulating two variables - frequency and difficulty- this study has demonstrated that certain genres are both frequent and difficult. Particular attention should be paid to 'review articles' in medicine and to 'informative articles', 'reports', 'business plans' and 'travel blog entries' in tourism. When corresponding with the public administration, the most frequent and most difficult textual genres do not overlap, although laypersons do tend to believe that certain relatively frequent genres including 'allegations', 'claims' and 'letters of complaint'- are difficult to write. However, in each of the three domains, the two variables do not tend to converge; indeed, in most cases, some types of texts are particularly frequent, while others pose writing difficulties. 
The results for each of the groups surveyed are also notable. Although a single group -laypersons- was surveyed in the domain of the public administration, in both medicine and tourism, this article has considered results for two different groups, students and professionals. In both cases, this comparison reveals differences between both. In the medical domain, students and professionals tend to concur when selecting the most frequent textual genres, although they differ in assessing their difficulty levels. However, in tourism, although the most frequent genres differ from one group to another, the two groups tend to agree about the degree of difficulty in writing texts for these textual genres.

The results also demonstrate that similar challenges arise when writing specialized texts in each of the three domains. Indeed, the greatest difficulties when writing specialized texts are textual structure, content selection, and vocabulary use, followed by textual cohesion and degree of formality. Thus, this study has demonstrated that writing difficulties tend to cut across specialized domains. This conclusion is both relevant and interesting, as no previous studies have considered writing difficulties from an interdisciplinary perspective.

Future work could consider additional specialized domains and other textual genres. This would allow researchers to confirm the conclusions about specific writing difficulties and identify textual genres to which greater attention should be paid in other relevant domains including economics, politics, and environmental sciences. These conclusions have also underscored the descriptive, theoretical and social repercussions of this work.

Finally, the results indicate that writers have difficulties and needs when writing specialized texts. Related with this idea, we have developed an automatic system to assist in writing. This system bears in mind the writing difficulties noted by each of the groups studied in these domains. Based on the results, it focuses on the textual genres that they need to write most frequently and those that pose the greatest difficulties. The system, called arText (da Cunha, Montané \& Hysa, 2017), is available in the following URL: http://sistema-artext.com/

\section{REFERENCES}

Ayala, P., Domínguez, E., Martel, F., Montelongo, J., Morales, D., Socorro, O. J. \& Suárez, E. (2000). Manual de normalización de documentos administrativos. Las Palmas: Universidad de Las Palmas de Gran Canaria.

Barringer, B. R. (2014). Preparing effective business plans: An entrepreneurial approach. 2nd Edition. New Jersey: Pearson.

Bhatia, V. (1993). Analyzing genre: Language use in professional settings. London: Logman.

Cabré, M. T. (1999). La terminología. Representación y comunicación. Barcelona: IULA-UPF. 
Cabré, M.T. (2005). Recursos lingüísticos en la enseñanza de lenguas de especialidad. In J. Gómez de Enterría (Ed.), V Jornada-Coloquio de la Asociación Española de Terminología (AETER): Comunicar y enseñar a comunicar el conocimiento especializado. Madrid: Centro Virtual Cervantes.

Calvi, M. V. (2006). Lengua y comunicación en el español del turismo. Madrid: Arco Libros.

Calvi, M. V. (2010). Los géneros discursivos en la lengua del turismo: Una propuesta de clasificación, Ibérica, 19, 9-32.

Calvi, M. V. \& Mapelli, G. (Eds.) (2011). La lengua del turismo. Géneros discursivos y terminología. Bern: Peter Lang.

Cassany, D. (2007). Afilar el lapicero. Guía de redacción para profesionales. Barcelona: Anagrama.

Cassany, D. (2009). La palabra desafiante. Entrevista a Daniel Cassany. Lima: Universidad de Lima.

Castellón, H. (2001). El lenguaje administrativo. Formas y uso. Granada: Editorial La Vela.

Cheng, F-W. (2016). Constructing hotel brands: A multimodal analysis of luxury hotel homepages. Ibérica, 31, 83-108.

Ciapuscio, G. (1998). Los resúmenes de la revista Medicina: Un enfoque diacrónico contrastivo. Signo y Seña, 10, 217-243.

da Cunha, I. (2008). Hacia un modelo lingüístico de resumen automático de artículos médicos en español. Barcelona: Institut Universitari de Lingüística Aplicada, Universitat Pompeu Fabra.

da Cunha, I. (2016). El trabajo de fin de grado y de máster: Redacción, defensa y publicación. Barcelona: Editorial UOC.

da Cunha, I., Montané, M. A. \& Hysa, L. (2017). The arText prototype: An automatic system for writing specialized texts. Proceedings of the 15th Conference of the European Chapter of the Association for Computational Linguistics. Software Demonstrations, 57-60.

Escobar, M. A. (2011). English grammar and learning tasks for tourism studies. Unidad Didáctica. Madrid: UNED.

Faya, G. (2016). Propuesta de tipología textual para el campo médico. Revista Española de Lingüistica Aplicada, 29(1), 64-87.

Fregoso, G. (2008). Problemas del estudiante universitario con la redacción. Un estudio de caso en los niveles de licenciatura y de maestría. Revista Universidad EAFIT, 44(149), 9-22. 
Goethals, P. (2013). Travel blogs written by non-professionals: An exploratory analysis of a tourim genre. Iberica, 25, 147-170.

González Salgado, J. A. (2009). El lenguaje jurídico del siglo XXI. THEMIS: Revista de Derecho, 57, 235-245.

Gotti, M. (2008). Investigating specialized discourse. Bern: Peter Lang.

Gotti. M. \& Salager-Meyer, F. (Eds.) (2006). Advances in medical discourse analysis: Oral and written contexts. Bern: Peter Lang.

Gutiérrez, B. M. (1998). La ciencia empieza en la palabra. Análisis e historia del lenguaje cientifico. Barcelona: Península.

Helán, R. (2012). Analysis of published medical case reports: Genre-basedstudy. Unpublished doctoral dissertation, Masaryk University, Czech Republic.

Li, L-J. \& Ge, G-Ch. (2009). Genre analysis: Structural and linguistic evolution of the English-medium medical research article (1985-2004). English for Specific Purposes, 28(2), 93-104.

Magnet, A. \& Carnet, D. (2006). Letters to the editor: Still vigorous after all these years?: A presentation of the discursive and linguistic features of the genre. English for Specific Purposes, 25(2), 173-199.

Mapelli, G. (2013). El léxico de las guías descriptivas. In L. Chierichetti \& G. Garofalo (Eds.), Discurso profesional y lingüística de corpus. Perspectivas de investigación (pp. 125138). Bérgamo: CELSB.

Mapelli, G. (2016). Guías de viaje 2.0: Léxico y metadiscurso. Ibérica, 31, 149-174.

Mapelli, G. \& Piccioni, S. (2011). Taxonomía de los textos turísticos: Factores lingüísticos y factores contextuales. In M. V. Calvi \& G. Mapelli (Eds.), La lengua del turismo. Géneros discursivos y terminología (pp. 47-74). Berna: Peter Lang.

Marco, M. J. (2000). Collocational frameworks in medical research papers: A genrebased study. English for specific purposes, 19(1), 63-86.

Martínez Escalona, V. (2012). Análisis de los portales de viajes de los periódicos españoles de referencia. Los casos de 'elviajero.com' y 'ocholeguas.com'. Proceedings of the Actas IV Congreso Internacional Latina de Comunicación Social, Universidad de La Laguna, España.

Meza, P. (2015). La comunicación del conocimiento en el género Tesis de Lingüística: Comparación entre grados académicos. In G. Parodi \& G. Burdiles (Eds.), Leer y escribir en contextos académicos y profesionales (pp. 67-112). Santiago de Chile: Planeta. 
Ministerio de las Administraciones Públicas (2003). Manual de Documentos Administrativos. Madrid: Tecnos.

Montolío, E. (2014). Manual de escritura académica y profesional. Barcelona: Ariel.

Moreno, J., Rodríguez, B., Vázquez, M. D., Ricardo, Y. \& Rodríguez, A. (2016). Errores comunes cometidos por los estudiantes de 5to en la redacción de Informes de Casos. Proceedings of the $V$ Jornada Cientifica de la SOCECS, Holguín, Cuba.

Nwogu, K. (1997). The medical research paper: Structure and functions. English for Specific Purposes, 16(2), 119-138.

Pano, C. O., Picón, J. \& Attorresi, H. (2004). Las dificultades para la redacción de textos académicos en los estudiantes universitarios desde una perspectiva cognitiva. Proceedings of the XI Jornadas de Investigacion, Facultad de Psicología. Universidad de Buenos Aires, Argentina.

Parodi, G. (2001). Compresión y producción lingüística: Una aproximación al discurso argumentativo escrito. Letras, 63, 15-16.

Parodi, G. (Ed.) (2008). Géneros académicos y géneros profesionales: Accesos discursivos para saber y hacer. Valparaíso: Ediciones Universitarias de Valparaíso.

Parodi, G. (Ed.) (2010). Academic and professional discourse genres in Spanish. Amsterdam/Philadelphia: John Benjamins.

Parodi, G., Ibáñez, R. \& Venegas, R. (2014). ¿Cómo escribir un buen resumen? In E. Montolío (Coord.), Manual de escritura académica y profesional (pp. 93-119). Barcelona: Ariel.

Piqué-Angordans J. \& Posteguillo S. (2006). Medical discourse and academic genres. In K. Brown (Ed.), The Encyclopedia of Language and Linguistics (pp. 649-657). London: Elsevier.

Poirier, S. \& Brauner, D. J. (1990). The voices of the medical record. Theoretical Medicine and Bioethics, 11, 29-39.

Reimenerink, A. (2003). Las necesidades de traductores y especialistas para la redacción y traducción de artículos experimentales. In R. Muñoz Martín (Ed.), I AIETI. Actas del I Congreso Internacional de la Asociación Ibérica de Estudios de Traducción e Interpretación. Granada 12-14 de febrero de 2003 (pp. 119-140). Granada: AIETI.

Rodríguez Abella, R. M. (2013). El discurso de la promoción turística institucional en Internet. In L. Chierichetti \& G. Garofalo (Eds.), Discurso profesional y lingüística de corpus. Perspectivas de investigación (pp. 2017-242). Bergamo: CELSB. 
Rodríguez Abella, R. M. (2014). Reflexiones en torno al género boletín digital turístico: Situación comunicativa y análisis lingüístico. Normas: Revista de estudios lingüísticos hispánicos, 4, 117-133.

Rodríguez de Benítez, K. (2014). Implementación del proceso de producción escrita para el mejoramiento de la redacción de textos expositivos en Administración Hotelera. Cuaderno de Pedagogía Universitaria, 12(23), 42-54.

Sabaj, O. (2009). Descubriendo algunos problemas en la redacción de Artículos de Investigación Científica (AIC) de alumnos de postgrado. Revista Signos. Estudios de Lingüistica, 42(69), 107-127.

Salager-Meyer, F. (1990). Discoursal flaws in Medical English abstracts: A genre analysis per research- and text-type. Text, 10(4), 365-384.

Sánchez Alonso, F. (2014). Lenguaje y estilo administrativo. Redacción de documentos. Murcia: Escuela de Formación e Innovación. Administración Pública.

Spanish State Secretariat for Information Society and Digital Agenda (SESIAD) (2015). Plan for the Advancement of Language Technology [on line]. Retrieved from: http://www.agendadigital.gob.es/tecnologias-

lenguaje/Bibliotecaimpulsotecnologiaslenguaje/Detalle\%20del\%20Plan/PlanImpulso-Tecnologias-Lenguaje.pdf

Skelton, J. (1994). Analysis of the structure of original research papers: An aid to writing original papers for publication. British Journal of General Practice, 44, 455459.

Suau-Jiménez, F. \& Piqué-Noguera, C. (2017). Hedging in tourism discourse: The variable genre in academic vs professional texts. Proceedings of the Congreso Internacional de Lingüistica de Corpus, Paris, France.

Swales, J. M. (1990). Genre analysis: English in academic and research settings. Cambridge: Cambridge University Press.

Venegas, R., Núñez, M. T., Zamora, S. \& Santana, A. (2015). Escribir desde la pedagogía del género. Guias para Escribir el Trabajo Final de Grado en Licenciatura. Chile: Ediciones Universitarias de Valparaíso.

\section{NOTES}

${ }^{1}$ https://www.plainlanguage.gov/ [Last consulted: 04/07/2018]

${ }^{2}$ In this study, all the data were recollected in Spain and the interviews' and surveys' participants were also from this community. The following specialists were 
interviewed as part of this study: Antoni Trilla, Deputy Dean of Academic Affairs and International Relations at the University of Barcelona's (UB) Faculty of Medicine; Josep Basora, President of the Spanish Society of Family and Community Medicine (semFYC); M. Ángeles Escobar, instructor for the Bachelor's Degree in Tourism at the National Distance Education University (UNED); Marc Molas, Managing Partner of Planet Hotels \& Resorts and partner at By Pillow; and Núria Mallada, Comptroller at the Foradada City Council (Lleida). We would like to extend our sincerest appreciation to them for their assistance.

3 Recordings of all interviews are available on the project website: http://iriadacunha.com/FundacionBBVA2015/en/publications/ [Last consulted: 04/07/2018]

4 We would like to thank all of the survey respondents for their generous and invaluable contributions to this research project.

\section{* ACKNOWLEDGEMENTS}

This article is part of the "Automatic system to help in writing specialized texts in domains relevant to Spanish society" ("Un sistema automático de ayuda a la redacción de textos especializados de ámbitos relevantes en la sociedad española actual”) research project, which received a "2015 BBVA Foundation Grants for Researchers and Cultural Creators" ("Convocatoria 2015 de Ayudas Fundación BBVA a Investigadores y Creadores Culturales”) grant. This work was also supported by a Ramón y Cajal contract (RYC-2014-16935) associated with the Department of Foreign Philologies and their Linguistics at the National Distance the National Distance Education University (UNED). This research has been developed in the framework of the ACTUALing and IULATERM research groups. We would like to thank Josh Goldsmith for the translation of the text. 


\section{ANNEX 1. Survey results in the medical domain}

\begin{tabular}{|l|l|l|l|l|l|l|}
\hline \multirow{2}{*}{ List of textual genres } & \multicolumn{2}{|c|}{ Students } & \multicolumn{2}{c|}{ Professionals } & \multicolumn{2}{c|}{ Total } \\
\cline { 2 - 6 } & Freq. & Diff. & Freq. & Diff. & Freq. & \multicolumn{1}{c|}{ Diff. } \\
\hline popular science article & $1,1 \%$ & $5,6 \%$ & $1,8 \%$ & $14,0 \%$ & $1,4 \%$ & $8,9 \%$ \\
\hline short research article & $2,2 \%$ & $20,2 \%$ & $1,8 \%$ & $12,3 \%$ & $2,1 \%$ & $17,1 \%$ \\
\hline long research article & $1,1 \%$ & $16,9 \%$ & $5,3 \%$ & $50,9 \%$ & $2,7 \%$ & $30,1 \%$ \\
\hline review article & $25,8 \%$ & $34,8 \%$ & $7,0 \%$ & $21,1 \%$ & $18,5 \%$ & $29,5 \%$ \\
\hline letter to the editor & $0,0 \%$ & $0,0 \%$ & $0,0 \%$ & $1,8 \%$ & $0,0 \%$ & $0,7 \%$ \\
\hline letter of acceptance/rejection of a paper & $0,0 \%$ & $0,0 \%$ & $1,8 \%$ & $1,8 \%$ & $0,7 \%$ & $0,7 \%$ \\
\hline case report & $68,5 \%$ & $3,4 \%$ & $36,8 \%$ & $3,5 \%$ & $56,2 \%$ & $3,4 \%$ \\
\hline conference paper & $0,0 \%$ & $2,2 \%$ & $10,5 \%$ & $5,3 \%$ & $4,1 \%$ & $3,4 \%$ \\
\hline editorial & $1,1 \%$ & $1,1 \%$ & $0,0 \%$ & $1,8 \%$ & $0,7 \%$ & $1,4 \%$ \\
\hline health fact sheet & $0,0 \%$ & $1,1 \%$ & $1,8 \%$ & $1,8 \%$ & $0,7 \%$ & $1,4 \%$ \\
\hline medical history & $85,4 \%$ & $7,9 \%$ & $70,2 \%$ & $5,3 \%$ & $79,5 \%$ & $6,8 \%$ \\
\hline patient record & $21,3 \%$ & $3,4 \%$ & $33,3 \%$ & $5,3 \%$ & $26,0 \%$ & $4,1 \%$ \\
\hline technical report & $0,0 \%$ & $2,2 \%$ & $7,0 \%$ & $3,5 \%$ & $2,7 \%$ & $2,7 \%$ \\
\hline book & $1,1 \%$ & $12,4 \%$ & $0,0 \%$ & $12,3 \%$ & $0,7 \%$ & $12,3 \%$ \\
\hline textbook & $1,1 \%$ & $1,1 \%$ & $0,0 \%$ & $3,5 \%$ & $0,7 \%$ & $2,1 \%$ \\
\hline progress note & $13,5 \%$ & $3,4 \%$ & $10,5 \%$ & $0,0 \%$ & $12,3 \%$ & $2,1 \%$ \\
\hline web page & $0,0 \%$ & $1,1 \%$ & $10,5 \%$ & $7,0 \%$ & $4,1 \%$ & $3,4 \%$ \\
\hline syllabus & $0,0 \%$ & $1,1 \%$ & $3,5 \%$ & $1,8 \%$ & $1,4 \%$ & $1,4 \%$ \\
\hline conference program & $0,0 \%$ & $0,0 \%$ & $3,5 \%$ & $3,5 \%$ & $1,4 \%$ & $1,4 \%$ \\
\hline PhD proposal & $0,0 \%$ & $3,4 \%$ & $1,8 \%$ & $17,5 \%$ & $0,7 \%$ & $8,9 \%$ \\
\hline book review & $0,0 \%$ & $0,0 \%$ & $1,8 \%$ & $3,5 \%$ & $0,7 \%$ & $1,4 \%$ \\
\hline abstract & $11,2 \%$ & $10,1 \%$ & $7,0 \%$ & $5,3 \%$ & $9,6 \%$ & $8,2 \%$ \\
\hline peer review & $1,1 \%$ & $1,1 \%$ & $0,0 \%$ & $8,8 \%$ & $0,7 \%$ & $4,1 \%$ \\
\hline PhD thesis & $1,1 \%$ & $12,4 \%$ & $1,8 \%$ & $35,1 \%$ & $1,4 \%$ & $21,2 \%$ \\
\hline bachelor's thesis & $10,1 \%$ & $50,6 \%$ & $5,3 \%$ & $17,5 \%$ & $8,2 \%$ & $37,7 \%$ \\
\hline master's thesis & $1,1 \%$ & $3,4 \%$ & $0,0 \%$ & $12,3 \%$ & $0,7 \%$ & $6,8 \%$ \\
\hline other & $1,1 \%$ & $0,0 \%$ & $1,8 \%$ & $0,0 \%$ & $1,4 \%$ & $0,0 \%$ \\
\hline
\end{tabular}

\section{ANNEX 2. Survey results in the tourism domain}

\begin{tabular}{|l|l|l|l|l|l|l|}
\hline \multirow{2}{*}{ List of textual genres } & \multicolumn{2}{|c|}{ Students } & \multicolumn{2}{c|}{ Professionals } & \multicolumn{2}{c|}{ Total } \\
\cline { 2 - 7 } & Freq. & Diff. & Freq. & \multicolumn{1}{c|}{ Diff. } & \multicolumn{1}{c|}{ Freq. } & \multicolumn{1}{c|}{ Diff. } \\
\hline informative article & $5,2 \%$ & $32,8 \%$ & $27,0 \%$ & $39,4 \%$ & $20,5 \%$ & $37,4 \%$ \\
\hline travel blog post & $15,5 \%$ & $5,2 \%$ & $9,5 \%$ & $7,3 \%$ & $11,3 \%$ & $6,7 \%$ \\
\hline $\begin{array}{l}\text { Email (in hotels or other enterprises from the } \\
\text { tourist sector) }\end{array}$ & $55,2 \%$ & $3,4 \%$ & $56,2 \%$ & $4,4 \%$ & $55,9 \%$ & $4,1 \%$ \\
\hline travel brochure & $12,1 \%$ & $6,9 \%$ & $0,0 \%$ & $6,6 \%$ & $3,6 \%$ & $6,7 \%$ \\
\hline forum post & $12,1 \%$ & $1,7 \%$ & $9,5 \%$ & $5,8 \%$ & $10,3 \%$ & $4,6 \%$ \\
\hline travel guide & $22,4 \%$ & $6,9 \%$ & $3,6 \%$ & $6,6 \%$ & $9,2 \%$ & $6,7 \%$ \\
\hline report & $6,9 \%$ & $10,3 \%$ & $27,0 \%$ & $15,3 \%$ & $21,0 \%$ & $13,8 \%$ \\
\hline travel itinerary & $22,4 \%$ & $3,4 \%$ & $6,6 \%$ & $2,2 \%$ & $11,3 \%$ & $2,6 \%$ \\
\hline textbook & $1,7 \%$ & $12,1 \%$ & $0,0 \%$ & $0,0 \%$ & $0,5 \%$ & $3,6 \%$ \\
\hline rules and regulations & $0,0 \%$ & $20,7 \%$ & $5,8 \%$ & $21,2 \%$ & $4,1 \%$ & $21,0 \%$ \\
\hline business plan & $0,0 \%$ & $17,2 \%$ & $16,1 \%$ & $27,7 \%$ & $11,3 \%$ & $24,6 \%$ \\
\hline travel plan & $22,4 \%$ & $3,4 \%$ & $5,8 \%$ & $2,9 \%$ & $10,8 \%$ & $3,1 \%$ \\
\hline other & $3,4 \%$ & $0,0 \%$ & $6,6 \%$ & $7,3 \%$ & $5,6 \%$ & $5,1 \%$ \\
\hline
\end{tabular}




\section{ANNEX 3. Survey results for the domain of the public administration}

\begin{tabular}{|l|l|l|}
\hline \multirow{2}{*}{ List of textual genres } & \multicolumn{2}{|l|}{ Total } \\
\cline { 2 - 3 } & Freq. & Diff. \\
\hline allegation & $10,0 \%$ & $13,8 \%$ \\
\hline authorisation & $23,8 \%$ & $3,8 \%$ \\
\hline cover letter & $23,8 \%$ & $12,5 \%$ \\
\hline formal letter & $18,8 \%$ & $8,8 \%$ \\
\hline notice & $18,8 \%$ & $3,8 \%$ \\
\hline curriculum vitae & $40,0 \%$ & $3,8 \%$ \\
\hline declaration & $3,8 \%$ & $3,8 \%$ \\
\hline affidavit & $2,5 \%$ & $16,3 \%$ \\
\hline affidavit & $3,8 \%$ & $3,8 \%$ \\
\hline lawsuit & $3,8 \%$ & $16,3 \%$ \\
\hline accusation & $1,3 \%$ & $13,8 \%$ \\
\hline formal request & $16,3 \%$ & $7,5 \%$ \\
\hline statement of grounds & $5,0 \%$ & $5,0 \%$ \\
\hline notification & $11,3 \%$ & $5,0 \%$ \\
\hline official letter & $3,8 \%$ & $6,3 \%$ \\
\hline petition & $10,0 \%$ & $3,8 \%$ \\
\hline letter of complaint & $10,0 \%$ & $8,8 \%$ \\
\hline complaint & $0,0 \%$ & $12,5 \%$ \\
\hline claim & $13,8 \%$ & $10,0 \%$ \\
\hline administrative appeal & $3,8 \%$ & $40,0 \%$ \\
\hline appeal for revision & $0,0 \%$ & $8,8 \%$ \\
\hline ordinary appeal & $2,5 \%$ & $10,0 \%$ \\
\hline letter of resignation & $2,5 \%$ & $1,3 \%$ \\
\hline application & $33,8 \%$ & $3,8 \%$ \\
\hline suggestion & $7,5 \%$ & $1,3 \%$ \\
\hline other & $0,0 \%$ & $5,0 \%$ \\
\hline & & \\
\hline
\end{tabular}

\section{ANNEX 4. Survey results: Difficulties when writing specialized texts}

\begin{tabular}{|l|c|c|c|c|c|c|c|}
\hline \multirow{2}{*}{ Writing difficulties } & \multicolumn{3}{|c|}{ Medicine } & \multicolumn{3}{c|}{ Tourism } & Admin. \\
\cline { 2 - 8 } & Stud. & Prof. & Total & Stud. & Prof. & Total & Total \\
\hline $\begin{array}{l}\text { Knowing what kind of structure to use } \\
\text { when writing this text. }\end{array}$ & $66,3 \%$ & $52,6 \%$ & $61 \%$ & $50,0 \%$ & $38,0 \%$ & $41,5 \%$ & $58,8 \%$ \\
\hline Using the right vocabulary. & $40,4 \%$ & $29,8 \%$ & $36,3 \%$ & $60,3 \%$ & $21,2 \%$ & $32,8 \%$ & $56,3 \%$ \\
\hline $\begin{array}{l}\text { Avoiding spelling or other linguistic } \\
\text { mistakes. }\end{array}$ & $7,9 \%$ & $1,8 \%$ & $5,5 \%$ & $43,1 \%$ & $5,1 \%$ & $16,4 \%$ & $15 \%$ \\
\hline Using the right degree of formality. & $24,7 \%$ & $28,1 \%$ & $26 \%$ & $37,9 \%$ & $27,7 \%$ & $30,8 \%$ & $30 \%$ \\
\hline Deciding what content to include. & $62,9 \%$ & $57,9 \%$ & $61 \%$ & $27,6 \%$ & $46,7 \%$ & $41 \%$ & $36,3 \%$ \\
\hline $\begin{array}{l}\text { Ensuring text cohesion in the ways ideas } \\
\text { are presented. }\end{array}$ & $39,3 \%$ & $57,9 \%$ & $46,6 \%$ & $25,9 \%$ & $32,1 \%$ & $30,3 \%$ & $18,8 \%$ \\
\hline $\begin{array}{l}\text { Finding examples of this kind of text to } \\
\text { use as models. }\end{array}$ & $14,6 \%$ & $19,3 \%$ & $16,4 \%$ & $22,4 \%$ & $19,7 \%$ & $20,5 \%$ & $11,3 \%$ \\
\hline $\begin{array}{l}\text { Knowing who will be reading this text } \\
\text { and how to speak to them. }\end{array}$ & $12,4 \%$ & $12,3 \%$ & $12,3 \%$ & $10,3 \%$ & $17,5 \%$ & $15,4 \%$ & $21,3 \%$ \\
\hline Other & $1,1 \%$ & $1,8 \%$ & $1,4 \%$ & $1,7 \%$ & $6,6 \%$ & $5,1 \%$ & $2,5 \%$ \\
\hline
\end{tabular}

